\title{
formação da sociedade de classes \\ e a necessidade de descolonização \\ no brasil ${ }^{\star}$
}

\section{the formation of class society and the need for decolonization in brazil}

\author{
Jaime Winter León * \\ Instituto de Economia da Universidade Federal do Rio de Janeiro, Rio de Janeiro, RJ, Brasil \\ Maria Mello de Malta $\star \star$ \\ Instituto de Economia da Universidade Federal do Rio de Janeiro, Rio de Janeiro, RJ, Brasil
}

\section{RESUMO}

O objetivo é analisar as origens do processo de revolução burguesa no Brasil a partir da específica formação social brasileira sob o capitalismo dependente teorizada por Florestan Fernandes. A hipótese sinaliza que a origem do processo, iniciado com o golpe de 1930, remete à conformação colonial da sociedade brasileira e determinou: os condicionantes de uma sociedade tipicamente capitalista; um marco para a discussão do "povo" brasileiro; os caminhos de conformação da consciência de classe no Brasil, tanto burguesa quanto trabalhadora; e as possibilidades de mudanças sociais enquanto descolonização, ao condicionar o tipo de democracia possível. Este é um trabalho interdisciplinar sobre História do Pensamento Econômico Brasileiro e que segue o método das controvérsias do pensamento econômico elaborado por Malta e outros (2011).

Palavras-chave: Revolução burguesa. Descolonização. Raça. Democracia. Formação Social.

\section{Abstract}

The objective is to analyze the origins of the process of bourgeois revolution in Brazil since the specific Brazilian social formation under the dependent capitalism theorized by Florestan Fernandes. The hypothesis stresses that the origin of this process, initiated with the 1930 coup, refers to the colonial conformation of the Brazilian society and it has determined: the conditions of a typically capitalist society; the milestone for the Brazilian "people"; the ways that class consciousness in Brazil is shaped, both that of the bourgeoise and that of the working class; and the possibilities for social change as decolonization, by conditioning the type of possible democracy. This is an interdisciplinary work on History of Brazilian Economic Thought that follows the method of the controversies of economic thought developed by Malta et al. (2011).

Keywords: Bourgeois revolution. Decolonization. Race. Democracy. Social formation.

* Submissão: 24/03/2020; aprovação: 13/10/2020.

$\star \star$ Professor do Instituto de Economia da Universidade Federal do Rio de Janeiro. Pesquisador do Laboratório de Estudos Marxistas (LEMA - IE/UFRJ). E-mail: jaime.leon@ie.ufrj.br. ORCID: <https://orcid.org/0000-0001-8400-2801>.

$\star \star \star$ Professora do Instituto de Economia da Universidade Federal do Rio de Janeiro. Coordenadora do Laboratório de Estudos Marxistas Pesquisador do Laboratório de Estudos Marxistas (LEMA - IE/UFRJ).E-mail: mariammalta@yahoo.com.br. ORCID: <https://orcid.org/0000-0002-5538-940X>. 


\section{Introdução}

A formação social brasileira, categoria marxista que trata da complexidade de coexistência de mais de um modo de produção em um certo período e país, deu-se, desde a colonização europeia, por uma lógica diferente das formações dos países que atualmente são conhecidos como o centro da ordem global. Na verdade, em grau, ritmo e intensidade distintos, a sociedade de classes nos países da América Latina foi construída com uma característica comum à periferia: a influência do desenvolvimento desigual e combinado. Tal ideia foi cara a Florestan Fernandes, um militante e sociólogo marxista, que será a referência do debate sobre a formação socioeconômica e da necessidade de descolonização do Brasil que é proposto neste trabalho. ${ }^{1}$

Os caminhos diferentes que os processos de formação da "nação" assumiram, tanto no centro como na periferia, determinaram o alcance, as possibilidades e as finalidades das revoluções burguesas latino-americanas. Afirma-se que na América Latina, em geral, e no Brasil, em particular, o processo de formação social, na direção da construção de nações, no sentido de coletividades com um projeto autodeterminado de futuro e orientado para os anseios da maioria da população, não foi completado e determinou um tipo de revolução burguesa específica: a revolução burguesa dependente. Essa é uma marca do início de organizações societárias tipicamente capitalistas estruturadas em classes sociais conflitantes.

A revolução burguesa periférica também conformou Estados que expressam sua forma de dominação e direção políticas numa forma específica, estabelecendo parâmetros para a democracia que se estabeleceu na região. A seguinte afirmação de Octavio Ianni, discípulo direto de Florestan Fernandes, aponta esse sentido das mudanças vistas:

$\mathrm{Na}$ América Latina, a revolução burguesa compreende um processo histórico de ampla envergadura, com surtos, descontinuidades, recuos.

1 A ideia de desenvolvimento desigual e combinado foi formulada por León Trotsky a partir da formulação de desenvolvimento desigual de Lenin e se baseava basicamente na existência de tempos históricos distintos dentro de um mesmo país e nas relações assimétricas entre países no cenário internacional causadas pelo ritmo distinto em que o capitalismo foi penetrando os diferentes países e regiões do globo. 
Conforme o país, desenvolve-se larga e contraditoriamente, desde as revoluções de independência e entrando pelo século XX. Há casos em que os seus principais desenvolvimentos se dão em algumas décadas. Naturalmente são diversas e muito peculiares as condições nacionais sob as quais se dá a revolução burguesa. Mas é possível dizer que essas condições, em cada um e em todos os países da América Latina, não produziram a consolidação da democracia. Ao contrário, consolidou-se o Estado forte, abrangente, autoritário, intimamente acoplado com o poder econômico, bastante vinculado aos interesses estrangeiros. (Ianni, 1988, p. 2)

O objetivo aqui é dar um passo atrás na análise sobre o processo de revolução burguesa e aprofundar o debate sobre sua origem e seu desencadeamento no Brasil a partir da contribuição da formação social brasileira sob o capitalismo dependente elaborada por Florestan Fernandes. A hipótese sinaliza que esse processo, iniciado com o golpe de 1930, remete à conformação colonial da sociedade brasileira e determinou: os condicionantes de uma sociedade tipicamente capitalista no país; um marco para a discussão do "povo" brasileiro; os caminhos de conformação da consciência de classe no Brasil, tanto burguesa quanto trabalhadora; e as possibilidades de mudanças sociais enquanto descolonização, ao condicionar o tipo de democracia possível dentro dos marcos destacados por Octavio Ianni.

O que se tratará de fazer é ver as conexões entre identidade, povo e nação concretizadas nessa formação social colonial. Isso será feito a partir de um resgate da perspectiva crítica de Florestan Fernandes, um intelectual orgânico das massas. ${ }^{2}$ Assim, este é um trabalho interdisciplinar de História do Pensamento Econômico Brasileiro (HPEB) e História Econômica que faz uma interpretação histórica, econômica e

2 O intelectual orgânico é para Gramsci ([1934] 1999-2006) a pessoa que se constrói politicamente junto com a classe à qual ele está aderido e que tem como função dar homogeneidade e construir, junto com a classe, a consciência desta classe para atingirem um novo projeto de sociedade. Defende-se que Florestan Fernandes foi um intelectual orgânico nesse sentido por sua trajetória de vida, de sua atuação política em partidos que tinham como bandeira a defesa dos interesses da classe trabalhadora (Partido Socialista Revolucionário na década de 1940 e Partido dos Trabalhadores no fim da década de 1980 até meados da década de 1990) e suas bandeiras de luta em áreas como a educação pública, as causas indígena e negra, a luta pela democratização no período do Estado Novo, durante o regime civil-militar entre 1964 e 1985, durante o período Constituinte e por sua trajetória acadêmica. 
sociológica da formação brasileira. A contribuição do texto é retomar, num período onde a discussão de classes está praticamente posta de lado, a linha de interpretação da teoria da dependência, da qual Florestan é importante representante, e resgatar a importância da categoria de capitalismo dependente para o estudo do Brasil. ${ }^{3}$ Ao longo dessa argumentação, sempre que possível, a obra de Floresta Fernandes será comparada com a de outros intérpretes do Brasil, a fim de sublinhar convergências ou divergências.

Vale comentar que no plano da discussão da descolonização, Florestan Fernandes está dentro de um grupo de autores que pensaram a necessidade de descolonização na América Latina, como, por exemplo, José Mariátegui e Aníbal Quijano no Peru, ou autores que pensam esse processo fora da América, como Achille Mbembe na África e Edward Said no Oriente Médio. Apesar do reconhecimento da importância desses debates, o debate aqui apresentado será centrado no caso brasileiro. ${ }^{4}$

O método utilizado é o construído coletivamente para a HPEB em Malta e outros (2011) e desenvolvido em Curty e Malta (2019). Segundo tal método, a História do Pensamento Econômico (HPE) é um campo de disputa de ideias, na qual o mesmo objeto pode ser reivindicado de diferentes formas por interpretações distintas. Nesse sentido, não há na HPE linearidade cumulativa de conhecimento. Este é marcado por descontinuidades, rupturas e reviravoltas, pois a HPE é o próprio pensamento em processo, em movimento. Assim, a HPE pode

3 Florestan foi um marco na discussão da teoria da dependência. Além de sua interpretação, no Brasil, existem outras interpretações a partir da ideia de dependência que merecem ser citadas como: a teoria marxista da dependência deVânia Bambirra, Theotônio dos Santos, Ruy Mauro Marini e André Gunder Frank; a teoria da dependência weberiana de Fernando Henrique Cardoso e Enzo Faletto; as teorias do capitalismo dependente, como de Octavio Ianni e Carlos Nelson Coutinho; as teorias do capitalismo tardio, como de João Manoel Cardoso de Mello e Maria da Conceição Tavares; ou ainda a teoria do subdesenvolvimento estruturalista de Celso Furtado.

4 Vale comentar que, como lembram Pradella (2016) e Badaró (2019), o debate sobre descolonização ou simplesmente anticolonial já estava presente em Marx nos estudos sobre a Índia e a China na década de 1850, no qual Marx conecta as questões coloniais com as crises sistêmicas do capitalismo, está presente também durante a década de 1860 ao escrever sobre a guerra civil estadunidense e mais adiante na década de 1870 quando Marx se debruça sobre a questão irlandesa. 
ser contada através das controvérsias sobre cada objeto de pesquisa. A HPEB trataria justamente das controvérsias da formação do Brasil a partir dos pontos de vista dos chamados intérpretes do Brasil, pensadores que se debruçaram sobre o presente do Brasil a partir da pesquisa de seu passado com a finalidade de propor um projeto para o Brasil futuro. A controvérsia contada aqui é a da necessidade de descolonização da sociedade brasileira, uma formação nacional inconclusa que traz em sua dinâmica traços do passado colonial.

O pressuposto é que a revolução burguesa periférica no Brasil, assim como no restante da América Latina, foi originada na transição das sociedades coloniais para as sociedades de classes e conformou o capitalismo dependente (Fernandes, [1972] 1973). Tal variedade de capitalismo tem como característica própria a "dupla articulação" entre segregação social (e do estilo de dominação que ela pressupõe) e a dependência ao capital internacional (ditada pelas potências hegemônicas e pela relação das comunidades nacionais e o "mundo internacional dos negócios"), que produzem o subdesenvolvimento e a dependência indefinidamente como barreiras que impedem o controle dos meios e dos fins da mudança social de forma autônoma por parte do povo.

Além desta introdução e das considerações finais, este artigo conta com duas seções. A primeira trata das formas como se deram as organizações sociais no Brasil antes da conformação da sociedade de classes e quais os seus dínamos; a segunda trata de como o povo, sendo os elementos humanos negro, mestiço e indígena as bases da sociedade ao lado do branco, surgiu na formação social brasileira e aponta para os limites impostos à conformação de algo como uma "democracia brasileira" a ser construída.

\section{O sentido da construção do capitalismo no Brasil}

\subsection{A ordem social colonial}

A história do Brasil contemporâneo é a história da transição incompleta do Brasil colônia para o Brasil Nação (Prado Jr., [1942] 2011). Essa frase se refere à evolução dos fatos sociais, econômicos e políticos que se desenrolam desde a chegada dos portugueses no território que hoje 
se conhece como Brasil (note-se que há implícita uma ideia polêmica de que o Brasil contemporâneo passou a existir com a colonização). Ancorado nessa ideia de Caio Prado Jr., Fernandes ([1981] 2015) afirmaria que o dilema brasileiro em fins do século XX era que, na América Latina, a descolonização ainda estaria inconclusa.

A forma como o Brasil estava inserido no modo de produção capitalista se devia ao fato de o país ter sua história moderna como parte da expansão da civilização ocidental e do papel histórico que a colonização portuguesa teve para o país. Como resultado, não poderia existir, desde o começo da colonização, formas sociais que extrapolassem o desenvolvimento do ordenamento social que ocorria em Portugal ou na Europa durante os séculos XV a XVIII. Ao contrário, na colônia haveria a "tentativa de transplantação de um regime estamental português" (Fernandes, [1972] 1973, p. 13) combinada com elementos próprios da dinâmica que viria a vigorar na colônia, a saber: a grande plantação; a escravidão e a expropriação colonial (Fernandes, [1968] 1981).

A dependência brasileira seria construída pelos agentes históricos que moveram e movem a história do país de forma particular. Essa heteronomia é uma condição permanente, mas instável e mutável, dados os nexos da dependência (ora colonial, ora neocolonial, ora imperialista), da polarização da hegemonia global e do poder de determinação do núcleo dominante.

Desde os tempos coloniais, o país vem passando por transições da ordem social que vigora internamente. Segundo Fernandes ([1960] 2008), o foco central dos dinamismos das mudanças sociais é justamente a forma de organização da sociedade. A ordem social é, segundo a caracterização weberiana desenvolvida por Florestan Fernandes, a forma como a sociedade organiza suas relações econômicas, sociais, políticas e culturais em determinados períodos.

De acordo com Heló́sa Fernandes, filha do sociólogo, a categoria weberiana de ordem social diz respeito especificamente à ordem estamental, tipificada pela honra, pelo modo de viver e pela desvalorização do trabalho físico e é colocada em risco quando o lucro econômico e a aquisição material dominam o modo de viver. Portanto, a ordem social, em Weber, seria mais uma ordem econômica (Fernandes, 2015). Já a categoria de "ordem social" elaborada por Florestan Fernandes, extrapola essa noção weberiana ao assumir a possibilidade de múltiplos orde- 
namentos sociais num mesmo tempo e por se preocupar com as tendências sociais de mudanças. Esse traço de mudanças sociais é uma influência de Émilie Durkheim sobre o autor brasileiro. Como o próprio Florestan aponta, seu trabalho teórico foi construído sob uma rotação de perspectivas que não são mero amálgama, mas síntese das discussões relevantes de autores como Weber, Marx e Durkheim (Fernandes, [1968] 1981). De Marx, Florestan teria retido principalmente sua preocupação com a transformação revolucionária da sociedade.

Como ressalta Ricupero (2015), tanto Prado Jr. ([1942] 2011) quanto Fernandes ([1975] 2011) dão um caráter especial à existência e à relação entre o setor da economia voltado "para dentro" e o setor voltado "para fora". ${ }^{5}$ Segundo Caio Prado Jr., haveria na sociedade colonial, de um lado, um "setor inorgânico" orientado para as atividades que sustentavam indiretamente as atividades principais de exploração extrativa ou que não podiam ser classificadas como relacionadas à grande exploração rural, como a pecuária e a agricultura necessárias para a sustentação do mercado que garantia a subsistência da vida social internamente e atividades como a vadiagem, a prostituição etc.; já, de outro lado, o "setor orgânico" seria composto por todas as atividades relacionadas diretamente à grande exploração e, basicamente, sustentadas pelo braço escravo.

Ambos, Caio Prado Jr. e Florestan Fernandes, apontariam a relevância que o setor voltado para dentro passaria a determinar para a formação social brasileira. Florestan também se aproximaria de Caio Prado Jr. ao apontar que, após a independência, a estrutura econômica da sociedade colonial persistiria, mas somente aos poucos iria abrir a possibilidade de internalização das fases de comercialização da produção; por fim, ambos convergem na ideia de que a formação de um Estado nacional foi um marco para a sociedade brasileira a partir do acontecimento histórico de 1822, a Independência política.

5 Apesar de reivindicar e seguir os trilhos de Caio Prado Jr., Florestan se afasta do historiador ao apontar a transição da predominância do capital mercantil para o capital industrial, o que, adiante, no período de industrialização por substituição de importações, daria ao processo de industrialização - através da modernização um potencial subestimado por Caio Prado. Por fim, vale destacar que a análise de Florestan explora muito mais sociologicamente os dínamos internos da sociedade brasileira que a obra de Caio Prado Jr. (Ricupero, 2015; Fernandes 1995). 
A maneira pela qual a história, enquanto prática da vivência das relações sociais de homens e mulheres, é conformada em determinados períodos é o horizonte teórico de Florestan Fernandes. Assim, para ele, é fundamental recorrer às ordenações sociais que antecederam o regime de classes no Brasil para que se possa entender os condicionantes e as possibilidades postas para uma ordem social em classes.

Segundo o militante paulistano, durante quase três séculos o sistema de colonização e de dominação externo brasileiro, e do restante da América Latina, foi construído de acordo com o "antigo sistema colonial". Este subordinava a colônia à metrópole. Combinadas algumas das categorias teóricas de Prado Jr. (1979) e Furtado ([1972] 1975), vemos como o sociólogo paulistano aponta que vigorou um regime de grande empresa agrária assentado na força de trabalho escrava, no latifúndio monocultor e na produção primária voltada para o exterior que conformava um verdadeiro "sistema de poder", o qual subordinava os trabalhadores rurais à lógica do "sentido da colonização". Essa rede de negócios fazia com que fosse necessário um aparelhamento institucional da colônia para dar vazão ao fluxo de escravos no país.

No que concerne aos termos sociológicos da sociedade colonial, esse antigo sistema de subordinação da colônia exigia fundamentos legais e políticos que permitissem que os interesses da coroa e dos colonizadores pudessem ser garantidos institucionalmente e, mais importante, que pudessem ser reproduzidos e intensificados. Então as estruturas de estratificação social ibérica foram transplantadas para o Brasil e para o restante da América Latina, sendo adaptadas à instituição do trabalho escravo negro, mestiço e nativos e do trabalho forçado dos nativos. Formou-se um sistema colonial estratificado com a combinação de castas e estamentos em que a exploração era ilimitada. Segundo o sociólogo:

[...] uma combinação de estamentos e castas produziu uma autêntica sociedade colonial, na qual apenas os colonizadores eram capazes de participar das estruturas existentes de poder e de transmitir posição social através da linhagem "européia". A estratificação resultante, porém, possuía grande flexibilidade, favorecendo a absorção e o controle de massas de nativos, africanos e mestiços, classificados em categorias de castas ou mantidos fora das estruturas estamentais, como estratos dependentes. (Fernandes, [1972] 1973, p. 13) 
Essa combinação peculiar do sistema de castas - que refletia uma hierarquia social sem mobilidade e determinada pela herança familiar aos escravos e indígenas - com o sistema de estamentos - o qual refletia uma hierarquia social determinada pelo prestígio social dado pelo poder monárquico e que garantia pouca mobilidade social entre os setores privilegiados - seria marca da ordem social colonial e uma especificidade sociológica brasileira (Fernandes [1972] 1973). ${ }^{6}$

Conforme o sociólogo, tentou-se transplantar a ordem social portuguesa a fim de construir-se um "novo-Portugal". As especificidades dos trópicos, da pilhagem e da abundância de terras impuseram ao colonizador limites para a classificação estamental, porém esta só viria a funcionar para os brancos, na maioria portugueses. Fora dessa ordem gravitavam as populações nativas que foram transformadas de "aliados" e "submetidos" para uma situação de "escravos de fato". Com a subsequente disputa por territórios e pelo uso da força de trabalho nativa para extração de pau-brasil e para uso nas feitorias, o status de escravos para os nativos foi institucionalizado. Com a posterior produção de açúcar com força de trabalho negra, as diferenças do ordenamento social português com o ordenamento realmente existente no Brasil ficaram ainda mais patentes.

De acordo com Fernandes ([1976] 2010), a estrutura social estamental era, basicamente, composta por uma raça branca dominante e pela força de trabalho escrava nativa, negra e mestiça. Entre elas havia uma população livre de posição incerta: mestiça de brancos e indígenas, com identidade de lealdade e de solidariedade com os setores dominantes,

6 Sobre a especificidade da formação social brasileira, segue Florestan Fernandes: "Suscitaram-se falsos debates, resultantes de uma distorção mecanicista do determinismo econômico ou da explicação dialética, como a tentativa de restabelecer a 'sociedade feudal' sobre a escravidão mercantil. Ou proscreveram-se conceitos, como o de casta e estamento, essenciais para a explicação de sociedades estratificadas nas quais a desigualdade econômica, social e política não se vincula ao capital industrial (e, portanto, à institucionalização do trabalho livre e da mais-valia relativa). Aqueles conceitos encontram largo uso entre os especialistas da sociologia histórica e da sociologia comparada - e mesmo os criadores do marxismo, Marx e Engels, os utilizam quando pretendem introduzir um máximo de saturação histórica no manejo das categorias gerais. Ao se evitar o emprego simultâneo de conceitos e categorias históricas como 'casta', 'estamento' e 'classe' perde-se, portanto, aquilo que seria a diferença específica na evolução da estratificação social no Brasil.” (Fernandes, [1976] 2010, p. 62-63). 
mas que nem sempre era incluída na ordem estamental, dependendo do grau de crescimento colonial em cada região geográfica. Este setor ambíguo mestiço (branco e indígena) servia como uma força paramilitar subserviente aos setores dominantes que garantia a proteção do território, a defesa de povoações e a demarcação de novas fronteiras.

Já os escravos indígenas, africanos e mestiços formavam em relação aos setores estamentais (brancos portugueses e mestiços brancos e indígenas), uma subordem de castas. Seria com a posterior libertação dos escravizados que a esses setores seria concedida a condição estamental, embora ainda fossem tratados sob uma situação de castas. Tal ordenação pressupunha expectativas de tratamento e de comportamento hierárquico de estamentos aristocráticos.

Nesse quadro, é necessário frisar o que representa a "periferia" no âmbito de uma colônia de exploração tal como foi o Brasil. Nela, por mais que os senhores participassem do esbulho colonial e tivessem acesso regular e institucionalizado ao processo de acumulação de capital mercantil ao participar do comércio de escravizados e do comércio de outras mercadorias, esses mesmos setores dominantes internos se viam limitados pela falta de interesse das nações hegemônicas externas e das metrópoles de imprimir um padrão de produção e organização social análogo, ou mesmo similar, ao que prevalecia na Europa. Em outras palavras: os setores dominantes no Brasil - embrenhados na escravidão e com o capital comercial através do capital mercantil - não tinham como tirar benefícios dos "efeitos de infiltração" do capitalismo industrial, pois não estavam inseridos na realidade dos países europeus (Fernandes, [1976] 2010). ${ }^{7}$

Segundo o autor, o modo de produção escravista associado ao capital comercial e ao investimento em capital mercantil baseava-se na

Segundo Cano (2010), o capital mercantil é anterior à acumulação primitiva, pois existe desde que começam as trocas mercantis de bens e serviços. Koutchin (2015) destaca as especificidades da discussão sobre o capital comercial e capital mercantil na quarta parte do livro três de O Capital de Marx. Segundo Koutchin, o capital mercantil se subdivide em duas formas: o capital comercial e o capital financeiro. O que faz Marx seria diferenciar como as formas funcionais do capital industrial (capital-mercadoria e capital-dinheiro) se convertem em capital comercial e capital financeiro (formas funcionais do capital mercantil). O capital comercial seria a forma como o capital se transforma na esfera da circulação de mercadoria para dinheiro e de dinheiro para mercadoria. 
apropriação do trabalho escravo e na exploração da força de trabalho escravizada. Porém, a apropriação e a exploração do escravizado, que era quem gerava excedente econômico, davam-se com fins de perpetuação do circuito comercial e não para mero usufruto do senhor de escravizados.

Seguindo a argumentação de Florestan Fernandes, ao contrário do que se tem como senso comum, durante o período colonial a escravidão não era o núcleo econômico da colônia e nem o elemento central de perpetuação do patrimonialismo, quem tinha essa função era a terra. Como destaca Ricupero (2015), ao contrário da obra de Faoro ([1958] 2011) acerca da existência e função do patrimonialismo brasileiro advindo da precocidade do absolutismo do Estado português, Florestan explora a categoria do patrimonialismo, como, aliás, já haviam feito Vianna ([1920] 2005), Freyre ([1936] 2013) e Holanda ([1936] 1995), antes dele. Para Florestan Fernandes, o patrimonialismo, uma categoria de influência weberiana, teria se consolidado com a Independência na medida em que a figura do "senhor-cidadão" ganha poder de comando exponencialmente na vida social, inclusive tendo dentro do Estado, após o fim da dependência política com relação a Portugal, uma fonte de socialização dos privilégios senhoriais em forma estamental através de um quadro administrativo para gerir essa socialização.

O império português contava com um complexo Estado patrimonialista que se desdobrava desde o poder do soberano para a nobreza, o clero e os homens ricos, interna e externamente, que conformavam uma verdadeira empresa militar, econômica, política e religiosa. Essa afirmação é importante, pois é dessa origem patrimonialista do Estado português, em que os vassalos reportam ao suserano, que se origina a concentração da propriedade fundiária no Brasil.

Segundo Fernandes ([1976] 2010), a doação de sesmarias tinha a função de transferir a estrutura estamental de Portugal para o Brasil. Ao demarcar estruturas de poder, que não deveriam ser alteradas, a base societária do Estado patrimonialista português se mantinha. As doações de sesmarias concentravam socialmente a terra criando o latifúndio e excluindo o grosso da população livre da posse da terra e, logo, do poder local e do direito de ter relações diretas com o Estado. Portanto, a terra, no Brasil, aparece desde os tempos coloniais como uma figura que confere privilégios e dominação.

A ordem estamental portuguesa, quando transplantada para o Brasil, 
foi profundamente alterada pelo contato com a escravidão. Esta esvaziou aquela de muitas de suas funções econômico e sociais. A produção agroexportadora colonial contava com um substrato humano muito heterogêneo que extrapolava a divisão entre "senhores" e "escravizados". A estrutura social tinha na figura do branco um imperativo estratégico que fazia com que a escravidão não existisse no vácuo e acabava por exigir o desenvolvimento de alguns povoados com um mínimo de funções urbanas. Nesse sentido, para Florestan Fernandes, a escravidão tornava a ordem estamental portuguesa débil e inflexível na medida em que todos os estamentos viam os escravizados como indispensáveis para tudo e colocavam o "povo miúdo" em um "conformismo sociopático". Assim, castas e estamentos eram superpostos, o estamento dominante ficava com o controle da situação e colocava os outros estamentos e estratos a reproduzirem os interesses senhoriais.

A superposição de estamentos de uma "raça" dominante e de castas de "raças" dominadas era muito complexa por combinar patriarcalismo com patrimonialismo e paternalismo com burocracia e colocava a ordem colonial em permanente tensão. O uso da força bruta em sua forma mais selvagem coexistia com a violência institucionalizada e legitimada pela "sacralidade" das tradições, da moral católica, do código legal e do Estado. O escravizado era posto como inimigo doméstico e inimigo público e o poder era monopolizado e utilizado livremente por uma minoria sempre que ela o achasse conveniente para a manutenção da ordem (Fernandes, [1976] 2010).

Havia uma "racionalidade senhorial" que imperava sobre os fluxos das concessões aos escravizados, mas, em linhas gerais, havia forte resistência a que a estruturação estamental e de castas da colônia fosse alterada, pois significaria uma mudança nas estruturas e dinamismos de poder da colônia. Destaca-se o fato de que a ordem colonial era muito dura com a figura da pessoa escravizada. Como o povo colonizador não era suficientemente numeroso, ele realizava uma transição demográfica no sentido de libertar alguns escravizados para preencherem funções mecânicas. Além disso, de acordo com as flutuações do mercado mundial, a pessoa escravizada era jogada da economia de plantação para a economia de subsistência.

Já o Estado, só atuaria contra o senhor nas situações em que o livre gozo do poder senhorial se tornasse tão violento a ponto de transgredir 
níveis considerados "normais". Se a violência do senhor acarretasse instabilidade no sistema de dominação e eventuais riscos para a ordem, o Estado intervia. Mas ele não atuava de forma a promover qualquer tipo de proteção ao agente humano objeto de escravidão.

Vale lembrar que, conforme aponta a pesquisa de Martins (2017), o Brasil não possuía um "código do negro" que protegesse minimamente o escravizado e a escravizada no tocante às suas condições morais, fisicas e sociais de vida. O que existia era um conjunto aleatório de alvarás e regimentos monárquicos e imperiais que versavam muito mais sobre as condições do tráfico negreiro. Note-se, entretanto, que havia a preocupação para que as pessoas capturadas e escravizadas chegassem vivas e em condições mínimas para serem exploradas em terras brasileiras. É nesse sentido que se pode falar que existia uma espécie de "código negreiro", e não um "código do negro" que visava à proteção da dignidade do elemento negro, tal como existia nas formas de exploração e dominação vigentes na França em 1685 e na Espanha, com a Real Cédula de 1789. Tal discussão remete, dentro das controvérsias que estão sendo apontadas, à discussão feita por Joaquim Nabuco, expoente do movimento abolicionista em fins do século XIX, em $O$ abolicionismo (Nabuco, [1883] 2000).

Joaquim Nabuco versa sobre o tema afirmando que a constituição de 1824, a fim de defender ideais liberais, não versava sobre o tema da escravidão, como se essa instituição inexistisse no Brasil. As questões referentes aos escravizados eram, no máximo, consideradas pelo Código Civil, que era marcado pela brutalidade que o senhor podia empregar no trato com o elemento negro. O senhor de escravo tinha a propriedade sobre este. $\mathrm{O}$ elemento negro contava como uma mercadoria e, portanto, o senhor poderia fazer com ela praticamente tudo que lhe desse vontade, desde que não transgredisse os direitos de propriedade de outros. Martins (2017), também sobre o tema, afirma que o conjunto de alvarás e regimentos sobre o assunto se preocupavam, basicamente, com as condições do tráfico, condições de fiscalização que refletiam na arrecadação desse comércio e, no máximo, com questões de segurança pública que brutalizavam, com claro teor racista, o elemento negro que praticasse crimes. Toda essa legislação ignorava as condições desumanas de captura, de transporte até o litoral e as condições de vida que cabiam ao elemento escravizado. Afirma também que isso era feito com vistas 
a garantir a rentabilidade do negócio negreiro, fato ao qual se junta a deliberada política de não incentivo à reprodução do negro em terras brasileiras. $^{8}$

Para Florestan Fernandes, o sistema de colonização e dominação colonial entrou em crise, principalmente, por três fatores:

1) A metrópole portuguesa (assim como a metrópole espanhola, no caso do restante da América Latina) não era econômica nem politicamente forte o bastante para garantir o financiamento de atividades de descoberta, exploração e crescimento da colônia. Por essa razão, a metrópole portuguesa seria suplantada porVeneza e, posteriormente pela Holanda, que forneceram as bases financeira, tecnológica e comercial para a exploração das colônias e tornaram-se os núcleos do capitalismo mercantil. Os novos epicentros desse tipo de capitalismo tornaram a dinâmica vigente muito onerosa para os agentes privilegiados e exploradores coloniais, e, logo, eles pressionaram pela emancipação política dos países latino-americanos.

2) A luta entre as potências coloniais - Holanda, França e Inglaterra - pelo controle das colônias latino-americanas, combinada às mudanças econômicas, políticas e culturais da Europa de fins do século XVIII e começos do século XIX desencadearam a desagregação do controle externo das potências ibéricas sobre suas colônias.

3) Por fim, havia setores das populações coloniais que eram duramente afetados pela rigidez da ordem colonial e eram diretamente interessados na destruição do antigo sistema colonial.Tais setores, em sua maioria, provinham de descendência mista e se identificavam com a internalização do poder econômico e político.

Segundo o sociólogo, a partir dessa crise, a transição da ordem colonial para a ordem neocolonial se deu como uma transição pacífica,

8 Segundo Paes (2013), no Brasil vigoraram até 1916 as Ordenações Filipinas de 1603 que tratavam da questão do escravizado em sua maioria no âmbito do Direito Civil e do Penal.Apesar de diversas disposições terem sido revogadas ao longo do século XIX com o advento do Código Criminal de 1830 e do Código de Processo Criminal de 1832, o direito civil continuou sendo orientado por aquelas ordenações. O comércio do elemento humano negro era muito lucrativo para a coroa portuguesa e, depois, para o império britânico. Este fato histórico sobre as condições dos escravizados foi notado por Marx (1867 [2012]) ao falar sobre o intenso fluxo de navios negreiros com destino ao Brasil na cidade Liverpool no século XVIII no seu capítulo sobre acumulação primitiva. 
uma revolução dentro da ordem e de modo a incorporar o Brasil no mercado mundial. Esta foi a chave para a longa duração do antigo sistema colonial, só que a partir de então esse sistema se daria em novas bases.Apesar de todas as tensões e de todos os conflitos, a associação dos colonos com o império foi mantida muito íntima e o colono nunca se tornou um agente autônomo, sempre foi um correspondente do poder imperial.

Nas palavras de Fernandes ([1976] 2010, p. 81), “o colono de status senhorial não só era o vassalo e o representante da coroa na colônia: ele era, simultaneamente, a base material visível e a mão armada invisível da existência do império colonial". O patrimonialismo fundou as bases dessa interdependência entre colono e coroa. Enquanto o poder da coroa era baseado num Estado patrimonial do império, o do colono se baseava na plantação, no modo de produção escravista. Aqui chegamos a um ponto chave de nossa proposta.

A ordem social colonial foi a forma como sociedade brasileira foi estruturada nos três primeiros séculos de colonização europeia. Ela nasceu com a tentativa de transplantação do sistema português para o Brasil, mas ao ter contato com a realidade e as funcionalidades da vida na colônia, essa ordem social resultou em algo totalmente distinto do que era em Portugal. Foi com a vinda da família real em 1808 e, principalmente, com a Independência política de 1822, uma verdadeira revolução política, que o país se emanciparia politicamente de Portugal para estreitar e intensificar os laços de dependência econômica com as potências capitalistas. Essa transição instaurou os germes de uma revolução burguesa no Brasil e os traços de permanência do status colonial, apesar de findada a dependência política.

\subsection{A ordem social neocolonial}

Em sua obra mais madura de interpreação do Brasil, $A$ revolução burguesa no Brasil, Fernandes ([1975] 2011) mostra que no caso brasileiro, o processo de desagregação do antigo sistema colonial é marcado por uma longa trajetória iniciada com a vinda da família real portuguesa para o Brasil, o que demandou a criação de novas instituições em território brasileiro. Se, no plano político, a Independência concertada com Portugal em 1822 representou a emancipação política do Brasil em 
respeito à sua metrópole, não representou uma emancipação no plano econômico, pois o sentido da colonização brasileira se manteve orientado pelos negócios de exportação de produtos primários - o Brasil passaria a participar do mercado triangular entre Europa, África e América - com um mercado interno incipiente correspondente à reprodução básica de condições de vida da engrenagem do grande setor exportador. Esse momento histórico instaurou as bases da dependência comercial em relação à potência emergente no capitalismo industrial, a Inglaterra do período da Pax Britannica (1815-1914).

A Independência marcou, portanto, o começo da era moderna no Brasil, pela qual uma série de ideias, instituições sociais e técnicas vindas da Europa chegavam ao Brasil ao nível das normas de comportamento, de cooperação ou conflito. Essas mudanças se deram ao longo do tempo histórico europeu, isto é, sob o controle dos interesses dos agentes europeus e dos setores internos associados àqueles interesses. Mais do que o começo do regime capitalista, a era moderna foi marcada pela crise do "antigo sistema colonial".

A emancipação "nacional" representou transformações econômicas importantes à medida que houve o desaparecimento da apropriação colonial e implicou o desenvolvimento de um novo setor da economia urbano-comercial, embora não tenha representado o rompimento da estrutura baseada em torno do monopólio da terra, da propriedade do escravizado e dos privilégios da aristocracia. Com a redefinição, pela aristocracia agrária, do controle das funções administrativas, políticas e legais, que eram historicamente da coroa, o Estado senhorial e escravista pode prevalecer.

Portanto, pela mudança econômica, a apropriação colonial que os senhores agrários faziam foi extinta e se transformou em apropriação do produto do trabalho regulada a partir de dentro e, pela primeira vez, pelos interesses da aristocracia agrária sem o peso de "espoliação colonial”; como uma mudança política importante, o Estado passou também a ser controlado pelos interesses econômicos senhorias que promoviam uma política econômica de autodefesa que não alterou o estatuto da escravidão e a condição do escravo (Fernandes, [1976] 2010).

$\mathrm{Na}$ verdade, a Independência, para Florestan Fernandes, significa a criação de uma espécie de Estado nacional nos marcos possíveis do prolongamento do colonialismo ao nível econômico, dependência cultural 
e social e emancipação política. Ao contrário de Oliveira Vianna, um dos pais do pensamento social autoritário no Brasil, para o sociólogo paulistano, o Estado não surge sem vínculo com o meio social do qual surge (um clã de fazendeiros que lutam entre si). Para Florestan, é justamente pelo Estado que os interesses das oligarquias, e futuramente das burguesias brasileiras, poderiam ser universalizados e defendidos como interesses de um estamento ou classe social, dando um caráter essencialmente político à revolução burguesa. ${ }^{9}$

O beneficiamento do senhor aristocrata ficaria claro com a expansão da economia do café (Fernandes, [1976] 2010). Esse ciclo expansivo significou o auge do ordenamento de estamentos e castas e resultou na expansão das esferas de participação na vida econômica dos senhores, os quais passaram a voltar seus interesses para as cidades. Por ser, basicamente, o único setor social que concentrava capital (isso era feito por meio da expropriação do trabalho escravo), os senhores eram os principais agentes que se destacavam na corrida para se transformarem em homens de negócios tipicamente capitalistas, por mais que tenham prolongado ao máximo o uso da força de trabalho escravo.

Tal dependência foi orientada pela ocupação do "vácuo econômico" deixado por Portugal. Muito mais do que ter exercido um poder imperial, a Inglaterra usufruiu da rede de exportação já montada e, como os produtos internos não tinham alto valor econômico e o mercado consumidor era relativamente grande, foi mais vantajoso o controle das esferas comerciais e financeiras, o que acabou por desenvolver os centros urbanos do Brasil.

O desmonte do antigo sistema colonial seria consolidado, segundo Fernandes ([1976] 2010), por dois processos históricos fundamentais para a sociedade brasileira: a abolição da escravidão em 1888 e a proclamação

9 Ainda no campo das controvérsias, Florestan Fernandes teria também uma visão sobre o idealismo utópico das burguesias brasileiras distinto de Oliveira Vianna. Segundo o primeiro, realismo e idealismo, atribuídos a conservadores e liberais seriam uma unidade, lados da mesma moeda, que promoveram de modo revolucionário um embrião de sociedade nacional, mas que manteve a antiga estrutura social. Autonomia e heteronomia seriam uma unidade dialética. Já para Vianna, haveria uma disputa entre idealistas utópicos e idealistas orgânicos conservadores. Para os primeiros, bastaria a cópia das instituições liberais europeias para que algo como um self-government fosse criado; e para os segundos, haveria diferenças substanciais entre os estados europeus e as nações latino-americanas (Ricupero, 2015). 
da república em 1889. Antes, porém, desde meados do século XIX, com a formação do que ele chamaria de "capitalismo competitivo", já se pode falar que os setores estamentais conhecido como "senhores” já se identificavam como um grupo com interesses econômicos, políticos e sociais comuns e com força para monopolizar o poder político estatal e comandar a economia interna. Os senhores adotariam um liberalismo que se resumia na liberdade do senhor e que impedia qualquer possibilidade de revolução nacional. Portanto, data da época neocolonial, época em que nasce o capitalismo no Brasil, a conformação da classe capitalista brasileira, no sentido de conformação de uma consciência de classe "em si" e "para si" para os senhores no país que unia a oligarquia tradicional do Vale do Paraíba com a oligarquia moderna do Oeste Paulista. ${ }^{10}$

$\mathrm{O}$ antigo sistema colonial produziu o agente principal de que precisava: o senhor colonial. De mentalidade ultraconservadora e egoísta, este agente satisfazia-se com seus próprios e mais imediatos interesses. O período de crise da ordem escravocrata e senhorial surgiu de baixo para cima com as dificuldades impostas para manutenção da escravaria e da reprodução do trabalho escravo. Nessa época foi intensificada a expansão do setor capitalista novo, baseada na força de trabalho livre após a abolição, que se difundiu das cidades para o campo, adaptando os senhores a uma nova realidade histórica. Conforme descrito por Florestan:

Portanto, apogeu e crise aparecem como dados concomitantes. O senhor

10 Vale comentar que a noção de modernidade da oligarquia do Oeste Paulista, tratada por Fernandes ([1975] 2011), deve ser ponderada. Paula Beiguelman, importante referência para o estudo da formação socioeconômica e política brasileira por ter se debruçadoem temas como a transição do trabalho escravizado para o trabalho livre e os aspectos políticos do complexo cafeeiro brasileiro, apresenta a crítica da ideia culturalista de que os fazendeiros do Oeste Paulista foram homogeneamente inovadores e modernos, em oposição aos fazendeiros do Vale do Paraíba, supostamente atrasados. Segundo Beiguelman (1977), dentro do Oeste Paulista poder-se-ia traçar uma diferença entre um "antigo Oeste Paulista", centrado em Campinas, que se empenhou em ficar ligado aos traços do regime escravista; e um novo Oeste Paulista, centrado em Ribeirão Preto, no qual as plantações de café se desenvolveram já após a decadência e o fim do tráfico de escravos. Por essa característica, o novo Oeste Paulista, desde o seu início, teve fortes conexões com a imigração e teve, consequentemente, vantagem na disputa por força de trabalho numa sociedade em que o trabalho livre e subvencionado pelo Estado ganhava centralidade. 
não sai dessas transformações como era antes. Porém, se ele aproveita, agora em estilo tradicional-patrimonialista e em estilo capitalista, o momento de apogeu, ele não se converte em vítima da crise final dessa ordem. A vítima foi o "negro" como categoria social, isto é, o antigo agente do modo de produção escravista que, quer como escravo, quer como liberto, movimentara a engrenagem econômica da sociedade estamental e de castas. Para ele não houve "alternativa histórica". Ficou com a poeira da estrada, submergindo na economia de subsistência, com as oportunidades medíocres de trabalho livre das regiões mais ou menos estagnadas economicamente e nas grandes cidades em crescimento tumultuoso, ou perdendo-se nos escombros de sua própria ruína, pois onde teve de competir com o trabalhador branco, especialmente o imigrante, viu-se refugado e repelido para os porões, os cortiços e a anomia social crônica. (Fernandes, [1976] 2010, p. 84)

Ao se preocupar com o que aconteceu dentro das sociedades coloniais, ou seja, com o processo de eclosão da onda modernizadora do nascente capitalismo na América Latina, o sociólogo afirma que as "economias exportadoras de gêneros tropicais" nasceram extremamente especializadas e que essa característica foi imposta pelas antigas metrópoles e pelo mercado mundial depois dos processos de independência. Não obstante, depois da emancipação política, os novos países não deixaram de ter uma "especialização colonial" que alimentava estruturas e dinamismos coloniais. Eles não podiam ser destruídos, uma vez que se almejava um tipo específico de modernização. Essa modernização seria própria de um capitalismo moderno, urbano, comercial e que deveria se difundir para o campo. Esta seria a modernização dependente (Fernandes, [1976] 2010).

De fato, o autor afirmaria que as formas de produção e estruturas coloniais vinham tanto de dentro como de fora. Os grupos dominantes e os países industriais dominantes e os dinamismos do mercado mundial impunham uma perene colonização que colocava a descolonização como uma realidade que, através de composições, revelariam um lado necessário do capitalismo da periferia da Europa e do nascente capitalismo industrial. Portanto é da conformação de uma sociedade neocolonial, em transição do antigo sistema colonial para uma sociedade de classes, que nasce a urgência da descolonização para Florestan Fernandes.

A adoção de instituições representativas durante a ordem neocolonial não visava excluir o "povo" da participação política e das estruturas do 
poder, ela servia como um instrumento para manter a concentração social do poder sob o controle das classes sociais dominantes e intermediárias. Portanto, foi erigida uma "sociedade civil ultrasseletiva" segundo a qual todas as funções do Estado poderiam ficar dentro da ordem vigente.

Esse período do século XIX, de controle de mercado e dos processos econômicos das colônias pelas novas potências hegemônicas e de desmonte do antigo sistema colonial, foi uma marca da transição da ordem social colonial para a ordem social neocolonial. A dominação externa deixa de ser direta para tornar-se indireta.A monopolização dos mercados latino-americanos se dá, dentre outras maneiras, através da expansão da rede bancária, financeira e comercial e do prosseguimento dos negócios agroexportadores dos setores dominantes, que, sob o argumento de que as colônias não possuíam estrutura econômica para produção dos bens importados, funcionavam de forma a concentrar os mercados latino-americanos nas mãos de poucos agentes econômicos.

Os primeiros impulsos de internacionalização de um mercado capitalista moderno foram sentidos, uma vez que os produtores de bens primários puderam absorver parte do que antes lhes era expropriado pela metrópole. A dominação externa seguia, todavia. Com a complacência dos setores dominantes, constituídos pelos produtores rurais, pelos agentes comerciais e os comerciantes urbanos. Portanto, Fernandes ([1972] 1973) afirmaria que o período neocolonial reproduziu o status quo ante da economia, pois os esforços requeridos para mudar a estrutura econômica foram considerados tão dispendiosos para os setores sociais dominantes, que estes preferiram assumir um papel econômico subserviente e dependente sob as bases erguidas no antigo sistema colonial.

Com essa ideia, afirma-se que na fase neocolonial um novo tipo de relação entre escravidão mercantil e acumulação originária seria construído. Foi nessa época que o escravismo desempenhou certas funções construtivas para o desenvolvimento do capitalismo europeu e que o capitalismo comercial começou a se tornar uma realidade histórica brasileira. Os interesses comerciais e financeiros se concentraram nas cidades para organizar os negócios de exportação, o que consolidou o escravismo como base material do capitalismo comercial.

Além dos efeitos da crise do trabalho escravo, é necessário ponderar os "efeitos de encadeamento" do fim do ciclo da mineração, pois esta 
suscitou a expansão da economia de plantação para outras regiões e colocou o escravizado no centro de uma revolução econômica dentro da ordem. A transição para o ciclo do café se deu em sentido horizontal com a incorporação de novas fronteiras à economia agroexportadora. Como alerta Fernandes ([1976] 2010), a história brasileira tem sido contada através de uma perspectiva branca e senhorial, deixando agentes humanos e econômicos fundamentais de fins do século XIX na penumbra: o negro e a negra e os mestiços. A escravidão mercantil tornaria esses agentes sociais a base material de reprodução da ordem senhorial e escravocrata e a base da ordem de classes que estava por nascer, por mais que seus status humano fosse restaurado.

Ao aderir à república, os senhores, agora na sua versão burguesa de fazendeiros, resolviam o problema que a abolição impusera, contratavam a força de trabalho imigrante e abandonavam os antigos escravizados à sua sorte. Mais importante: salvavam o monopólio da terra e o poder oligárquico impondo à revolução burguesa iminente seus próprios ritmos históricos, combinando elementos "arcaicos e modernos" e o seu padrão mandonista. O sociólogo sintetiza a ideia da transição da ordem colonial para a neocolonial desta forma:

Portanto, a ordem escravocrata e senhorial foi destruída a partir de dentro, através de desenvolvimentos capitalistas direta ou indiretamente engendrados pela economia de plantação escravista; e foi, ao mesmo tempo, suplantada e substituída a partir de fora, pelos desenvolvimentos capitalistas que se irradiaram da economia urbano-comercial para a sua periferia agrária. (Fernandes, [1976] 2010, p. 95)

A digressão feita até aqui consistiu em apontar as características de organização social nos períodos denominados ordem social colonial e ordem social neocolonial.A exposição não foi desenvolvida em detalhes propositalmente. Primeiro porque não se poderia aqui aprofundar a análise de quase quatro séculos de colonização formal e, segundo, porque se pretende construir um caminho de argumentação para mostrar, e aqui sim com profundidade, a conformação da sociedade de classes no Brasil como algo específico a essa formação social.

Se, até agora, foi priorizada a sinalização dos aspectos que comandaram a dinâmica do sentido da colonização brasileira, relacionando-os 
aos interesses da metrópole portuguesa, das novas potências neocoloniais de fins do século XVIII e dos setores dominantes - produtores rurais, agentes e entrepostos comerciais exportadores e comerciantes urbanos - agora a análise será restrita naquilo que Fernandes ([1964] 2008) denominou como o surgimento do povo brasileiro: a abolição da escravidão em 1888 e seus impactos sobre a integração do negro e do mestiço na sociedade de classes. Será destacada a análise nos "condenados e semi-integrados ao sistema", parte fundamental e majoritária da sociedade brasileira. É crucial apontar que os fatos históricos da abolição e da proclamação da república marcam o começo de outra transição lenta de ordenamento social: da ordem social neocolonial para a ordem social de classes.

\section{3. $O$ surgimento do povo no Brasil e as possibilidades abertas à "democracia"}

A emergência de elementos de uma sociedade de classes no período neocolonial no Brasil foi marcada por uma especificidade: a questão do negro e da negra, assim como de mestiços e mestiças, enquanto sujeitos históricos de suma importância, tem conexão inexorável com aquele movimento. Segundo Florestan Fernandes ([1964] 2008), eles só emergem na sociedade civil como sujeitos capazes de desempenhar papel social ativo, enquanto povo, depois da formal abolição da escravidão. Vale dizer que não se considera aqui o povo como somente a massa da população representada pelos negros, negras, mestiços e mestiças, ou seja, aqueles que foram libertos pela abolição. Os indígenas e outras comunidades, chamadas de "minorias", como as outras etnias que constituem a realidade da população brasileira também estão incluídas. A questão é que a abolição influenciou a maioria da população ao influenciar direta e indiretamente com aqueles grupos mencionados.

Concomitantemente, acontecia na América Latina uma onda de revoluções burguesas periféricas que demarcariam as possibilidades de mudanças sociais em cada país. A solução encontrada na abolição, e em todos os movimentos legais relacionados à questão racial que a antecederam e a ela se seguiram, influenciou o grau de integração do negro, da negra, e dos mestiços e mestiças nas sociedade civil e política brasileiras. 
De acordo com Heló́sa Fernandes (2015), é em Fernandes ([1964] 2008) que o sociólogo eleva a discussão sobre o dilema social brasileiro de resistência às mudanças sociais, marca das classes dominantes no Brasil, a um outro patamar. Esse dilema seria um verdadeiro sintoma sociopático de apego às formas de dominação do passado, portanto as resistências às mudanças sociais eram psicológicas e políticas (Fernandes, [1960] 2008). O desenvolvimento da democracia ficava impedido pelo fato dessa resistência negar a condição de integrado àqueles que viriam a se apresentar como povo pela primeira vez no país: a massa de recém-libertos.

Conforme Cohn (2015), é em $A$ integração do negro na sociedade de classes que Florestan está analisando a dificil integração do povo, visto do "ponto de partida daqueles com pior ponto de partida histórico", com a constituição da sociedade de classes. O sociólogo paulistano estaria convencido de que tal processo ainda não estava completo e, segundo os elementos dinâmicos da sociedade dependente, não teria como ocorrer definitivamente nos marcos da ordem do capitalismo dependente. Segundo Cohn (2015), a dificuldade com que Florestan se depara nessa pesquisa é a de dar o salto entre a captura da figura vaga do povo para apreender a imagem específica da classe. Esse passo seria dado a partir de outro salto não trivial, da raça para a classe, o que, anteriormente, demanda a identidade dos negros, negras, mestiços e mestiças enquanto uma raça.

Como sinalizado, a emancipação "nacional” (independência política) não representou o colapso da economia colonial, pois a estrutura do antigo sistema colonial foi mantida. Para que houvesse uma crise daquela economia seria necessário que os escravizados, os libertos e os vários setores da população pobre participassem ativamente de um processo, inexistente, de descolonização. De acordo com Fernandes ([1976] 2010), a “crise final irreversível da escravidão" no Brasil data das quase três décadas entre 1860 e 1888 . Dialeticamente, se é verdade que sem a abolição não haveria capitalismo no Brasil, também confere que se chegara até aquele ponto de evolução do capitalismo graças à escravidão mercantil e que, como os fatos mostrariam, o fim do sistema escravocrata seria necessário para o desenvolvimento do capitalismo.

Nesse período de quase três décadas, há uma mudança qualitativa nas relações da economia urbano-comercial. O capital mercantil acu- 
mulado com a produção escravista pôde ser aproveitado, junto com o capital mercantil conseguido no exterior, na construção de uma infraestrutura econômica, na modernização urbana, no crescimento da grande lavoura, no incentivo à industrialização e também à imigração, na expansão da pequena propriedade etc., configurando um verdadeiro processo de mudança social em função da incipiente revolução burguesa.

Em relação à modernização, Florestan se aproxima de Gilberto Freyre, por apontarem que uma repetição de casos "clássicos" não se daria na periferia. De um lado, Freyre ([1936] 2013) aponta que com a mudança ocorrida no império com a preponderância da rua na vida social e dos "sobrados e mocambos", em detrimento da "casa grande e da senzala", haveria uma modernização conservadora algo positiva, mas que o conservadorismo do sociólogo o fez rejeitar. De outro lado, Florestan vê a forma específica que a revolução burguesa assume no Brasil também como uma modernização conservadora que, assim como em Freyre, traz um "equilíbrio de antagonismos". Porém, ao contrário do sociólogo de Apipucos, Florestan vê a revolução burguesa como limitadora da democracia no Brasil (Ricupero, 2015).

O Brasil foi o último país das Américas a abolir a escravidão e esse processo foi precedido de mudanças no quadro legal do país. Institucionalmente, em 1831, foi promulgada a Lei Feijó, segundo a qual os escravos desembarcados no país deveriam ser libertados. Na prática, porém, essa lei se mostrou ineficaz, uma vez que foi substancialmente ignorada; em meados do século XIX, a Inglaterra impusera o fim do tráfico negreiro com o Bill Aberdeen de 1845 - que seria oficialmente acatado pelo Brasil em 1850 com a promulgação da Lei Eusébio de Queiroz - que intencionava que os regimes escravistas fossem substituídos por regimes assalariados; em 1871, com a Lei do Ventre Livre, os recém-nascidos de mães escravas eram considerados livres e ficavam sob o cuidado dos senhores ou do Estado até que completassem vinte e um anos de idade e depois eram considerados livres; em 1885, foi promulgada a Lei do Sexagenário, pela qual os escravos que atingissem os sessenta anos estavam libertos; acontece que um escravo atingir tal faixa etária em meados do século XIX era algo raro e, logo, o que essa lei realmente fazia era desobrigar os senhores de escravos de se responsabilizarem por pessoas idosas que haviam sido escravas, uma vez que não tinham de considerar e providenciar as medidas mínimas de integração desses idosos na sociedade como cidadãos. 
Destacadamente, a mudança institucional mais relevante em termos socioeconômicos fora a Lei de Terras de 1850, que impedia a posse de terras por invasão ou por uso com fins de trabalho. Suas implicações são sentidas até os dias de hoje, seja com a aglomeração habitacional na periferia e nas favelas ou pelo falso "déficit habitacional", que coloca em marcha movimentos por terra e por moradias (falso, pois o que falta na verdade é uma melhor distribuição de terras e moradias). A sociedade de classes no Brasil nasceu, portanto, carregando o elemento característico de seu patrimonialismo.

Segundo essa Lei de Terras, a posse da terra ficaria restrita à compra pecuniária e à cessão por herança. As terras ocupadas de outra forma seriam confiscadas pelo Estado, que poderia aliená-las posteriormente. Ademais, a Lei de Terras previa subsídios governamentais para a imigração de força de trabalho europeia para servir de forma assalariada no Brasil. Essa lei representou, naquela transição de ordem neocolonial para uma sociedade de classes, o principal mecanismo legal perpetuador da dupla articulação entre segregação social interna e dependência externa, pois impedia que os futuros libertos pudessem ter qualquer tipo de acesso à propriedade fundiária e seria a base para a reprodução da grande exploração rural moderna tratada por Caio Prado Jr. (1979).

A abolição e seus desdobramentos se deram de forma a impedir a participação dos libertos e libertas na sociedade civil brasileira. Como destaca Paixão (2015), já em 1890, o Código Penal brasileiro punia manifestações da população negra e mestiça em praça pública, como a capoeira, o batuque, o espiritismo etc. Como mostra Ianni (1988;1989), a questão social foi convertida em questão de polícia, impedindo qualquer forma de conscientização de grupos com identidade de interesses comuns e contrários aos interesses dos grupos dominantes. Note-se, todavia, que no período da Primeira República (1889-1930) ainda não se pode falar em classes sociais plenamente constituídas no Brasil, pois o país ainda não se estruturava em dinamismos tipicamente capitalistas, a luta de classes típica do capitalismo ainda estava se desenhando.Assim, a questão racial foi muitas vezes retratada a partir de óticas culturalistas ou assimilacionistas, não levando em consideração a questão de classe, de opressão social e da resistência de negras e negros.

É verdade que Fernandes ([1972] 1973; [1975] 2011) trataria da emergência da classe burguesa no país como fruto de uma transformação dos 
setores cafeicultores, e agroexportadores em geral, em grupos cada vez mais atrelados aos interesses urbanos e associados aos interesse estrangeiros e que incorporavam os interesses políticos, financeiros e econômicos dos agentes comerciais e urbanos. Também procede que em $A$ integração do negro na sociedade de classes, o sociólogo faria um profundo estudo dos "condenados do sistema" e os caracterizaria como o povo brasileiro.

Por ser a cidade que mais intensamente apresentava o desenvolvimento do regime de classes e da incipiente revolução burguesa no Brasil, Florestan Fernandes elege São Paulo como ponto de análise desse período de transição. $\mathrm{O}$ autor mostra como a instauração e evolução de uma ordem social competitiva no fim do império e durante a Primeira República motivaram mudanças institucionais e uma liberalização jurídico-política orientada pelos interesses da adaptação da "grande empresa agrária" ao regime de trabalho assalariado e às relações de mercado implícitas.

Em vez de equiparar o agente recém-liberto com o trabalhador branco, nacional ou estrangeiro, a ordem que surgia expunha o negro e o mestiço ao desajustamento econômico, ocupacional e social. Os interesses dominantes da grande empresa agrária se transmutavam para o meio urbano e redefiniram geográfica, demográfica, econômica e socialmente o perfil de uma sociedade que passava de uma ordem de castas e estamentos para um regime de classes. Seria só com o início do processo de industrialização por substituição de importações no começo dos anos 1930, com as políticas varguistas, que o meio urbano se autonomizaria da grande empresa agrária.

A mensagem do sociólogo paulista era de que a sociedade que emergia no período neocolonial se mantinha fechada para os "mais iguais" - brancos nativos, em geral, e brancos estrangeiros - ao deixar negros e mestiços longe da integração positiva na nova ordem de classes. Assim, o autor mostra que a abolição de 1888 serviu, funcionalmente, muito mais ao agente branco que era senhor do que ao recém-liberto negro, pois este foi largado à sua própria sorte, tendo que se reeducar e se transformar para se adequar aos padrões de uma nova ordem sem receber qualquer espécie de reparação ou indenização por seus trabalhos forçados. Mais do que disso, nenhuma instituição existente, nem o Estado e nem a Igreja, responsabilizaram-se pelos libertos. 
Dessa forma, para o sociólogo, o negro, a negra, o mestiço e a mestiça foram deliberadamente colocados em um estado de anomia que os impediam de se formar como uma categoria social à parte ou mesmo de se integrarem às categorias sociais abertas à sua participação. Esse estado de anomia lhes colocavam uma barreira para que algo como uma "solidariedade de classe" pudesse emergir. Portanto, aquilo que Cohn (2015) apontara na obra de Florestan aparece claro aqui: não foram estimulados mecanismos de identificação dos elementos negro e mestiço com a raça e, tampouco, da raça com a emergente classe trabalhadora livre.

A tese sobre a integração do negro na sociedade de classes nascente feita por Florestan Fernandes causou controvérsia. Paixão (2015) aponta que, segundo alguns comentadores, como Célia Marinho de Azevedo, ao exaltar o estado de anomia do negro, do mestiço, da mestiça e da negra, Florestan acabou supervalorizando argumentações de que, por conta das sequelas do sistema escravista, o elemento negro teria ficado incapacitado de competir no mercado de trabalho. Dessa forma, as oligarquias modernas teriam priorizado o agente imigrante para as plantações de café. Sinaliza-se, sem intenção de resguardar Florestan, que essa afirmação não é errônea, mas deve ser ponderada. É verdade que a escolha pelo fator humano imigrante nas plantações de café foi uma escolha deliberada dos senhores e, como o Estado estava em função desses senhores, é verdade também que foi uma opção assumida institucionalmente pelo Estado brasileiro. A justificativa seria a de, ao se deixar ao relento os libertos, manter-se sob controle uma "revolução negra".

Porém, conforme apontado por Florestan, além de um definhamento material e moral de um estado de anomia, os próprios setores recém-libertos perceberam suas dificuldades em se ajustar às condições de integração e de expansão de uma ordem capitalista (Fernandes, [1964] 2008).Ao contrário de suposições de que os setores libertos "não tinham ambição", o sociólogo aponta que esses grupos, justamente por possuírem ambições de classificação social, autoimpuseram-se opções extremamente rígidas e negativas, colocando-se fora do surto capitalista. De certa forma, essa era uma forma de resistência da população negra.

O movimento de colocar o negro em estado de prostração era deliberado e respondia ao medo de que essa imensa parcela da população se revoltasse contra a ordem instituída. Portanto, se é verdade que os 
negros, as negras, os mestiços e as mestiças foram privados intencionalmente dos elementos econômicos, culturais e sociais de equiparação com os outros setores da sociedade, também vale, em parte, que esses próprios setores sociais refutavam uma classificação social através do assalariamento, tal como os imigrantes europeus faziam, devido ao histórico de dominação, humilhação e depredação moral que o trabalho braçal lhes ativava na memória. Conforme explica o autor:

A explicação desse fato parece se encontrar na peculiar condição psicossocial do elemento recém-egresso do regime servil. A sociedade escravocrata só preparou o escravo e o liberto para os papéis econômicos e sociais que eram vitais para o seu equilíbrio interno. No restante, prevaleceu a orientação de impedir todo florescimento da vida social organizada entre os escravos e os libertos, por causa do temor constante da "rebelião negra" [...]. Por isso, todas as formas de união ou de solidariedade dos escravos eram tolhidas e solapadas, prevalecendo a consciência clara de que só através da imposição de condições anômicas de existência seria possível conseguir e perpetuar a submissão dos cativos e a dependência fundamental dos libertos. (Fernandes, [1964] 2008, p. 73)

Este fato tinha implicações sobre as possiblidades de mudanças sociais por afetar as aspirações de mobilidade social dos setores mais diretamente impactados pela abolição. Então a anomia deliberadae imposta foi combinada com um processo deliberado de pauperização (empobrecimento e embrutecimento), acentuada no caso específico da cidade de São Paulo, e com a concorrência da força de trabalho europeia. Importante destacar: a pauperização, ao desorganizar socialmente o elemento negro, atuou como fator sociodinâmico essencial, mas a pobreza extrema não produziu a anomia. Nem, tampouco, a anomia produziu a situação de miséria. Foi a forma como o processo de pauperização se desenrolou socioeconomicamente que fez com que anomia e miséria se combinassem, se influenciassem e desfizessem quaisquer aspirações de ascensão dos setores libertos. Aos recém-libertos sobravam oportunidades de trabalho pré-capitalistas e de péssima remuneração e a impossibilidade de competição com o agente imigrante branco, pois a sociedade não enxergava o ex-escravizado como um concidadão. Nas palavras do autor:

O negro e o mulato não foram convertidos ao estado de extrema pobreza 
e dependência após um período de intensa participação das potencialidades culturais do ambiente. Sob vários aspectos, a escravidão redundou numa especialização restrita e fechada, que confinava a participação da cultura a um número reduzidíssimo de áreas e estimulava, ao mesmo tempo, como condição inexorável da dominação escravista, a perpetuação crônica da anomia social no convívio dos escravos entre si. Doutro lado, as formas de absorção do liberto na sociedade escravocrata e senhorial não corrigiram esses efeitos senão de forma parcial e incompleta. Em consequência, o negro e o mulato emergem na cena histórica paulistana como portadores de uma herança cultural tipicamente adaptada à sua situação, como agentes de trabalho pré-capitalista no mundo rústico adjacente. Eles não podem, por conseguinte, fazer face à competição com trabalhadores brancos, especialmente os de origem européia, e a substituição populacional adquire, para eles, um sentido estrito e impiedoso. Portanto, a pauperização do negro e do mulato na cidade de São Paulo possui traços específicos. Ela decorre da degradação que ambos sofreram com a perda do monopólio de certos serviços e sua exclusão concomitante, só corrigida incidentalmente (pelas oportunidades de trabalho fornecidas por formas econômicas pré-capitalistas subsistentes ou por áreas marginais da economia urbana), do sistema emergente de relações de produção. Trata-se, em suma, de uma pobreza associada quer à privação, em larga escala, de fontes regulares de ganho e de sustento, quer à adaptação inevitável a ocupações flutuantes, descontínuas e infimamente retribuídas. (Fernandes, [1964] 2008, p. 270-271)

Esse quadro implicava que o negro vivia nas cidades, mas não pertencia dinamicamente a elas. Essa era uma verdadeira situação de extremo isolamento cultural e de marginalização socioeconômica $\mathrm{O}$ progresso existia para o elemento branco ou imigrante; para o negro restou, em geral, o pauperismo, o desalento e a desorganização social. Após a abolição, de certa forma, o trabalho passou a ser a esperança de alguma classificação social para o recém-liberto na medida em que, através dele, o agente humano podia participar institucionalmente da vida social e tentar montar projetos de vida. Não obstante, o branco dominante ficou preso a um sistema de dominação racial de valores análogo aos da ordem estamental e de castas.

Segundo o sociólogo, a omissão dos setores brancos da sociedade lhes tornou efetivamente os principais responsáveis pela falta de "democracia racial”. Aliás, o mito de que existe democracia racial, expresso no ocultamento das opressões baseadas na raça, isenta de responsabilidade 
o branco no processo de exclusão do negro e do mestiço, atribui certa irresponsabilidade ao negro e conforma uma consciência da realidade racial brasileira espúria que perpetua parcialmente antigas formas de dominação patrimonialistas assentadas no desajuste entre a ordem racial de castas e estamentos e a ordem de classes. A democracia no Brasil aparece, então, como dependente da resolução da questão racial. Segundo Florestan:

A democracia surgiu tímida e debilitada em nosso meio. Como seu funcionamento e desenvolvimento normais dependem do poder relativo dos grupos sociais que concorrem entre si no cenário social, ideológica e utopicamente, ela forneceu, no início um palco histórico exclusivo aos poucos grupos sociais que estavam organizados, possuíam técnicas apropriadas para exercer a dominação e autoridade, e lutavam sem vacilações pelo monopólio do poder (se preciso, sob o manto dos "ideais democráticos"). O atraso da ordem racial ficou, assim, como um resíduo do antigo regime e só poderá ser eliminado, no futuro, pelos efeitos indiretos da normalização progressiva do estilo democrático de vida da ordem social correspondente. Enquanto isso não se der, não haverá sincronização possível entre a ordem social racial e a ordem social existentes. Os "brancos" constituirão a "raça dominante" e os "negros" a "raça submetida". Doutro lado, enquanto o mito da "democracia racial" não puder ser utilizado abertamente, pelos negros e pelos mulatos, como um regulador de seus anseios de classificação e de ascensão sociais, ele será inócuo em termos da própria democratização da ordem racial imperante. A dinamização no sentido democrático e igualitário da ordem racial tem de partir do "elemento de cor", embora deva ser tolerada, acolhida e sancionada pelos "brancos em geral". (Fernandes, [1964] 2008, p. 326-327)

Vale o comentário de que no trato da democracia e da descolonização vigente e possível no Brasil, Florestan se afasta de Sérgio Buarque de Holanda (Holanda, [1936] 1995) ao analisar a incipiente sociedade de classes de começos do século XX. Ao analisar o Brasil sob o período nazista e integralista, Sérgio Buarque aponta os traços da democracia no Brasil como um "lamentável mal-entendido", pois as classes dominantes (burguesas) brasileiras, rebentas das oligarquias, distorceram os princípios e valores das lutas burguesas europeias pela democracia liberal, adaptando-os de forma a manterem seus privilégios em terras americanas. 
Criaram uma caricatura de democracia burguesa imposta de "cima para baixo", dos dominantes para os dominados. As transformações vistas no Brasil, aliás, davam-se, segundo Sérgio Buarque, pelos intelectuais e por motivos sentimentais do "homem cordial", movido pelos impulsos do coração, atingindo a massa do povo despreparada para tais mudanças. Portanto, sua tentativa era de denunciar as tendências fascistas e autoritárias da manifestação desse movimento antidemocrático no Brasil (o integralismo) e de apontar mudanças bruscas na sociedade brasileira que, não coincidentemente, resultaram na emergência de um Estado autoritário (Estado Novo em 1937) apenas um ano após a publicação de Raízes do Brasil.

Caudilhismo e liberalismo são postos como antítese para Sérgio Buarque de Holanda ([1936] 1995), e a superação de ambos seria condição necessária para a concretização de "nossa revolução" proposta por ele, aquela que acabaria com os traços coloniais e patriarcais na sociedade brasileira, aquela que lidaria com a descolonização. De um lado, o personalismo caudilhesco seria a base da nossa vida social. De outro, o oligarquismo seria a manifestação no tempo e no espaço daquele personalismo que foi capaz de dar a aparência de estabilidade política em distintos momentos-chave de nossa história. A mensagem de Sérgio Buarque é uma esperança de transformações democráticas para o Brasil. Já Florestan Fernandes, em $A$ revolução burguesa no Brasil, vai além ao dar uma dimensão racial, social, política e econômica para a questão democrática no Brasil, porém com uma perspectiva mais restrita sobre as possibilidades de inclusão democrática.

Dentro do debate do mito da democracia racial e da necessidade de descolonização, vale apontar ainda que Clóvis Moura, um militante, sociólogo, jornalista e poeta negro, realizou uma crítica ao marxismo brasileiro. Segundo ele, o marxismo dominante no Brasil não conseguia apontar o racismo como elemento estruturante da sociedade de classes brasileira. Portanto, o marxismo brasileiro não conseguiria apontar o ponto fulcral da descolonização a se construir no Brasil. Clóvis Moura, no que toca ao desafio da questão racial e sua conexão com as classes e ao próprio destino da sociedade brasileira, foi além de Florestan Fernandes ao aprofundar o debate da questão da resistência negra, do processo de aculturação do negro e da reminiscência da lógica colonialista.

Em um artigo sobre Florestan Fernandes, Clóvis Moura (1995) afirma 
que as teses de Florestan Fernandes na década de 1960 foram importantes para desbancar o mito da democracia racial, porém eram demasiado acadêmicas. Entretanto, exalta Florestan Fernandes ao apontar que as polêmicas que ele suscitou seriam revistas ou mais bem explicadas quando o próprio Florestan esteve mais organicamente envolvido com o movimento negro durante o período em que atuou como deputado constituinte após o fim do regime civil-militar. O resultado dessa militância mais orgânica pode ser visto na obra Significado do protesto negro (Fernandes, [1989] 2017).

Assim, fica claro que para Florestan Fernandes o nascimento de uma sociedade tipicamente de classes no Brasil dependeu do sentido da colonização apontado por Prado Jr. ([1942] 2011) e que a democracia que se desenhava no país desde o princípio da revolução burguesa dependia da maneira como o povo brasileiro se encontrava e da possibilidade de descolonização total. ${ }^{11} \mathrm{O}$ golpe de 1930, sob a liderança de Vargas, marca o início do processo de revolução burguesa no sentido de que foi um ponto de inflexão da atuação, e aqui não importa se foi intencional ou não, do Estado brasileiro em direção à construção de uma sociedade de classes em vias de se industrializar em prol dos interesses das burguesias brasileiras (aquelas que nasceram dos setores agroexportadores e começavam a se autonomizar em relação ao meio rural nas cidades) e das burguesias estrangeiras. Ocorre, porém, que esse processo viria a reforçar o padrão de capitalismo dependente que Florestan Fernandes visualizou aumentando a segregação social e a dependência externa, dificultando ainda mais um debate sobre a possibilidade de a democracia no país prezar pela igualdade dos cidadãos e pela autonomia nacional.

\section{Considerações finais}

Décadas após a proclamação da Independência, que marcou a emancipação política de Brasil em relação a Portugal, a abolição da escravidão

11 Uma importante discussão feita contemporaneamente sobre o debate da descolonização brasileira a partir das ideias de Florestan Fernandes, Caio Prado Jr. e Celso Furtado está sintetizada em Sampaio Jr. (2017) e se direciona à tese de que o Brasil está em processo de "reversão neocolonial". 
e a proclamação da república marcaram a transição da ordem social colonial, na qual vigorava no Brasil uma total dependência econômica, política, cultural e social da colônia brasileira para a ordem neocolonial. Esta, por sua vez, manteve a lógica do antigo sistema colonial, sem que o Brasil mantivesse um status político de colônia. Essa ordem seria marcada no seu fim por uma potencial revolução social, na medida em que o povo pôde emergir na história com a libertação dos negros e mestiços, das negras e das mestiças, a base e a maioria da sociedade brasileira.

A libertação do elemento negro foi, porém, tutelada e controlada pelos grupos dominantes - oriundos sobretudo dos setores cafeicultores que passavam a voltar seus interesses para o meio urbano e por agentes e prepostos comerciais, financeiros e bancários dos setores exportadores, de forma a colocar os novos setores em um verdadeiro estado de anomia social, sem perspectivas concretas de serem integrados à nova ordem de classes que vislumbrava emergente, a ordem social competitiva (ou sociedade de classes). Ademais, a dinâmica do processo se deu de forma a pauperizar os setores recém-libertos, mantendo os traços patrimonialistas dos setores dominantes e a desorganização social dos mais vulneráveis.

Essa combinação de anomia e pauperismo atuou de forma a restringir condições objetivas e subjetivas para que revoltas e inconformismos sociais dos negros e negras, mestiços e mestiças se dessem dentro e mesmo contra a ordem de classes que emergia, não obstante a prévia conformação dos quilombos e outras formas de resistência. Assim, a democracia possível no Brasil estaria indelevelmente marcada pela necessidade de descolonização total, fosse econômica, política e cultural, e da efetivação da maioria da população como um povo que comanda seu destino a partir dos objetivos da maioria. Isso demandaria a inclusão dos recém-libertos nas sociedade civil e política que se formavam no fim da ordem social neocolonial e começo de uma sociedade de classes.

Este estudo foi um primeiro passo para o entendimento da formação social brasileira, do caminho histórico construído para a conformação de uma sociedade de classes no país e do que se entende por resistência às mudanças sociais no Brasil: a falta de vontade política das camadas dominantes de permitirem que algo como uma revolução econômica, democrática, popular e social ocorra de fato no país. Isso não necessariamente se dará nos marcos das revoluções burguesas tidas como clássicas, mas sim nas possibilidades impostas ao capitalismo dependente. 
O artigo aponta para a necessidade de uma pesquisa posterior, também de natureza interdisciplinar e com referência na análise de Florestan Fernandes, sobre como se deu efetivamente o processo de revolução burguesa no Brasil a partir do golpe de 1930 de Vargas e qual é o seu significado econômico, social e político uma vez concluído com o regime civil-militar iniciado em 1964. Esse processo histórico possibilitou a amplos setores da sociedade brasileira um estilo de vida mais próximo ao que se tem no centro do capitalismo mundial, mas reforçou a segregação social e a dependência externa. O presente estudo sobre a origem da revolução burguesa servirá de base para as reflexões sobre os limites e significado do desenrolar desse processo histórico.

\section{Referências}

BADARÓ, Marcelo. A classe trabalhadora de Marx ao nosso tempo. São Paulo: Boitempo, 2019.

BEIGUELMAN, Paula. (1973). Formação do povo no complexo cafeeiro: aspectos políticos. São Paulo: Editora da Universidade de São Paulo, 2005.

CANO, Wilson. Reflexões sobre o papel do capital mercantil na questão regional e urbana no Brasil. Texto para discussão IE-UNICAMP, Campinas, n 177. 2010. Disponível em <http://www.eco.unicamp.br/docprod/downarq.php?id=1807\&tp=a> . Acesso em 12 outubro 2020.

COHN, Gabriel. Florestan Fernandes: grandes problemas, grandes interlocutores. In: CEPÊDA,Vera.; MAZUCATO,Thiago. Florestan Fernandes 20 anos depois: um exercício de memória. São Carlos: UFSCAR, 2015. p. 33-46.

CURTY, Carla; MALTA, Maria. Elementos metodológicos para a organização da história do pensamento econômico brasileiro: a abordagem das controvérsias. In: COSENTINO, Daniel; GAMBI, Thiago (Org.). História do pensamento econômico brasileiro: pensamento econômico brasileiro. Niteroi: Eduff; São Paulo: Hucitec. 2019. p. 95-132.

FAORO, Raimundo. (1958). Os donos do poder? Formação do patronato político brasileiro, São Paulo: Globo, 2001.

FERNANDES, Florestan. Caio Prado Júnior: a rebelião moral. São Paulo, 1995. Disponível em <https://pt.scribd.com/document/110625208/Caio-Prado-Jr-Rebeliao-Moral-Florestan-Fernandes>. Acesso em 8 fevereiro 2019.

FERNANDES, Florestan. (1972). Capitalismo dependente e classes sociais na América Latina. Rio de Janeiro: Zahar, 1973.

FERNANDES, Florestan. (1976). O circuito fechado: quatro ensaios sobre o "poder institucional”. São Paulo: Globo, 2010. 
FERNANDES, Florestan. (1964). A integração do negro na sociedade de classes: ensaio de interpretação sociológica. São Paulo: Globo, 2008.

FERNANDES, Florestan. (1960). Mudanças sociais no Brasil: aspectos do desenvolvimento da sociedade brasileira. São Paulo: Global, 2008.

FERNANDES, Florestan. (1975). A revolução burguesa no Brasil: ensaio de interpretação sociológica. São Paulo: Globo, 2011.

FERNANDES, Florestan. (1981). Poder e contrapoder na América Latina. São Paulo: Expressão Popular, 2015.

FERNANDES, Florestan. (1989). Significado do protesto negro. São Paulo: Expressão popular; Fundação Perseu Abramo, 2017.

FERNANDES, Florestan. (1968). Sociedade de classes e subdeenvolvimento. Rio de Janeiro: Zahars, 1981.

FERNANDES, Heloísa. Florestan Fernandes, um sociólogo socialista. In: CEPÊDA, Vwe.; MAZUCATO, Thiago. Florestan Fernandes 20 anos depois: um exercício de memória. São Carlos: UFSCAR, 2015. p. 13-31.

FREYRE, Gilberto. (1936). Sobrados e mucambos. São Paulo: Global, 2013.

FURTADO, Celso. (1972). Análise do "modelo" brasileiro. Rio de Janeiro: Civilização brasileira, 1975.

GRAMSCI, Antonio. (1934). Cadernos do cárcer, v. 1-6. Rio de Janeiro: Civilização Brasileira, 1999-2006.

HOLANDA, Sérgio. (1936). Raízes do Brasil. São Paulo: Companhia das Letras, 1995.

IANNI, Octavio. A questão social. Revista USP, São Paulo, n. 145, p. 145-154, 1989.

IANNI, Octavio. As raízes da anti-democracia na América Latina. Lua nova, São Paulo, p. 17-22, 1988.

KOUTCHIN, André. Apontamentos sobre a conversão do capital-mercadoria e do capital-dinheiro em capital comercial e capital financeiro como formas do capital mercantil. VIII COLÓQUIO INTERNACIONAL MARX \& ENGELS, 2015, Campinas. Resumo: GT 1 - A obra teórica de Marx e Engels. 2015.

MALTA, Maria e outros. Ecos do desenvolvimento: uma história do pensamento econômico brasileiro. Rio de Janeiro: IPEA, 2011.

MARTINS, Roberto. A obsessão com o tráfico, a legislação escravista e os códigos negreiros portugues. XII CONGRESSO BRASILEIRO DE HISTÓRIA ECONÔMICA \& $13^{\text {a }}$ CONFERÊNCIA INTERNACIONAL DE HISTÓRIA DE EMPRESAS. Niterói: ABPHE, 2017.

MARX, Karl. (1867). O capital: crítica da economia política, v. 1. São Paulo: Boitempo, 2012.

NABUCO, Joaquim. (1883). O aboliocionismo. São Paulo: Publifolha, 2000.

PAES, Mariana. O tratamento jurídico dos escravos nas ordenações manuelinas e filipinas. V CONGRESSO BRASILEIRO DE HISTÓRIA DO DIREITO, 2013, Curitiba. Anais... Curitiba: IBHD, 2013.

PAIXÃO, Marcelo. Antropofagia e racismo: uma crítica ao modelo brasileiro de relações raciais, 2015. Disponível em < http://flacso.org.br/files/2015/10/ANTROPOFA- 
GIA-E-RACISMO-MARCELO-PAIX\%C3\%83O.pdf.> Acesso em 3 fevereiro 2019.

PRADELLA, Lucia. Crisis, revolution and hegemonic transition: the America civil war and emancipation in Marx's Capital. Science \& Society. v. 80, special issue, p. 454-467, 2016.

PRADO JR., Caio. (1942). Formação do Brasil contemporâneo: colônia. São Paulo: Companhia das Letras, 2011.

PRADO JR., Caio. A questão agrária no Brasil. São Paulo: Brasiliense, 1979.

RICUPERO, Bernardo. Florestan Fernandes e as interpretações do Brasil. In: CEPÊDA, Vera.; MAZUCATO, Thiago. Florestan Fernandes 20 anos depois: um exercício de memória. São Carlos: UFSCAR, 2015. p. 47-63.

SAMPAIO JR., Plínio. Crônicas de uma crise anunciada: crítica à economia política de Lula e Dilma. São Paulo: SG-Amarante Editorial, 2017.

VIANNA, Oliveira. (1920). Populações meridionais do Brasil. Brasília: Senado Federal, 2005. 